\title{
Catalysts for the utilization of methane from the coal mine ventilation air
}

\author{
${ }^{1}$ Beata Stasińska, Andrzej Machocki \\ University of Maria Curie-Sklodowska, Faculty of Chemistry, Department of Chemical Technology, 3 Maria Curie- \\ Sklodowska Square, 20-031 Lublin, Poland, e-mail: beata@hermes.umcs.lublin.pl \\ ${ }^{1}$ Corresponding author
}

\begin{abstract}
The paper indicates coal mines as the source of permanent emission of low-concentrated gases, which have increased the greenhouse effect. This paper proposes the catalytic oxidation of methane as the solution to the problem of methane utilization when its concentration in the air is insufficient for flame combustion. The studies which have been conducted for many years enabled finding the active oxide and metallic catalytic systems for the reaction of methane oxidation. For the utilization of gases with low-concentrated methane, using the low-temperature catalysts, especially palladium catalysts, seems to be economically well-justified. Depending on technological solutions it can be considered as the method for methane utilization or as an environmentally friendly way for the generation of electric and thermal energy.
\end{abstract}

Keywords: coal mine ventilation air, utilization of methane, catalytic oxidation of methane, oxide catalysts, palladium catalysts.

Presented at VII Conference Wasteless Technologies and Waste Management in Chemical Industry and Agriculture, Międzyzdroje, 12 - 15 June, 2007.

\section{INTRODUCTION}

Chemical industry is usually thought to be considerably responsible for the poor condition of natural environment. Therefore, in order to change the social perception of modern chemical industry, it is necessary to propagate the care of natural environment. It can be done by waste management, low-waste industrial technologies as well as by new chemical technologies designed for the management and minimization of the disadvantageous effects of other branches of industry. One of the examples could be the catalytic oxidation of methane that enables the utilization of methane emitted from coal mines and waste dumps.

Methane is 21 times more effective than carbon dioxide as the greenhouse gas. It means that a decrease of methane emission by 1 ton has the same effect as the 21 tons reduction of carbon dioxide emission1. The effective decrease of emission relating to carbon dioxide as the product of the combustion reaction is 18.25 tones of $\mathrm{CO}_{2}$ per 1 tone of $\mathrm{CH}_{4}$. The only instrument for the methane emission control is a charge for carbon dioxide and methane emission imposed on industrial plants, in Poland introduced in 1993. Very low charges, ca. 0.2 PLN per 1 ton of carbon dioxide or methane, are not very efficient in encouraging the managements of those plants to invest in new methods for the reduction of gases emission ${ }^{2}$. These fees cannot be thought as an element of the active climate policy, however they introduced the duty to monitor the greenhouse gases emission. The charges are not high, but if they are paid, they can have a beneficial effect on the economics of enterprises.

Because methane is tasteless and has no smell its small amounts are large enough to cause an accident. In the concentrations of $5-15 \%$, together with the air, it creates explosive mixtures which ignite at $810 \mathrm{~K}$. At a typical gassy mine, methane is emitted in three streams: methane ventilation air (VAM, $0.1-1 \%$ ), gas drained from the seam before mining ( $60-95 \%$ methane) and gas drained from the worked areas of the mine, e.g. goafs $(30-90 \%$ methane). Both in Polish and worldwide mining the largest problem is the utilization and economic use of methane from mine ventilation air, at which its concentration due to safety reasons is lower $(<0.75 \%)$ than the lower ignition limit of methane-air mixture. The data announced by the State Institute of Geology ${ }^{3}$ and by the Mining and Industry Ventilation internet site ${ }^{4}$ indicate that annually more than $70 \%$ of methane leaves the mines with ventilation air, which cannot be caught in the installations utilizing methane, and which creates methane-air mixtures with different methane concentration.

In the year 2003 the total flow of methane from Polish coal mines was $1522 \mathrm{~m}^{3} \mathrm{CH}_{4} /$ min. (825 million $\mathrm{m}^{3} \mathrm{CH}_{4} /$ year), when in the ventilation air it was $1132 \mathrm{~m}^{3} \mathrm{CH}_{4} / \mathrm{min}$. (595 million $\mathrm{m}^{3} \mathrm{CH}_{4} /$ year) and only $439 \mathrm{~m}^{3} \mathrm{CH}_{4} / \mathrm{min}$ (230 millions $\mathrm{m}^{3} \mathrm{CH}_{4} /$ year) $)^{3}$, was used by the drain installations ${ }^{4}$. From among Polish coal mines the largest amount of methane with ventilation air was emitted by the mine of Brzeszcze $-148 \mathrm{~m}^{3} / \mathrm{min}$. It corresponds to annual amounts of methane equal to 77,5 million $\mathrm{m}^{3}$. Over the last years in many Polish coal mines the underground installations for methane utilization have been constructed and the economic usage of grasped methane in thermalenergetic installations has been developed, but only when the concentration of methane is higher than $45 \%$. The associated energetic-cooling system used since the year 2000 in KWK „Pniówek”, should be mentioned as the positive example of such utilization of methane extracted from coal mines.

On the Polish market there is a lack of engineering solutions for low-concentrated methane utilization, similar to that developed by MEGTEC Systems (De Pere, Wisconsin, USA), CANTEM (Canadian Mineral and Technologies, Canada) or by Exploration CSIRO \& Mining and Energy Developments Limited (Australia) and which were already successfully used in some coal mines in the United States, Australia, Canada, Sweden and China ${ }^{1}$, 5,6 .

Catalytic oxidation of methane can be a way of methane utilization when its concentration is too low to burn in 
flame, e.g. in air leaving the mines. The catalytic process of methane oxidation is known since the end of the XXth century as the method of energy production from natural gas without the emission of nitrogen oxide. Catalysts enable the usage of low- or medium-oxidation temperatures to replace the flames combustion with flameless oxidation, oxidize low-concentrated methane in the mixture with air, even below $5 \%$ of methane, and create the process conditions under which thermal nitrogen oxides were not produced. Catalytic oxidation of methane enables the utilization of pure methane and low-concentrated gases, which can be used as the environmentally friendly source of energy that contributes to a complete management of methane in mines. Ventilation air from coal mines consists of nitrogen and oxygen, methane, carbon dioxide, water vapour. It may also contain traces of $\mathrm{CO}, \mathrm{C}_{2} \mathrm{H}_{6}$ and higher hydrocarbons, $\mathrm{He}, \mathrm{H}_{2}, \mathrm{HCN}, \mathrm{NH}_{3}, \mathrm{NO}_{\mathrm{x}}, \mathrm{H}_{2} \mathrm{~S}, \mathrm{SO}_{2}$ or organic sulfur compounds, ${ }^{4,8}$. The content of methane in the ventilation air depends on the way of its extraction ${ }^{4}$. The example ${ }^{8}$ of the composition of ventilation air from the coal mine is presented in Table 1.

Table 1. The average composition of mine gases form working and liquidated mines ${ }^{8}$

\begin{tabular}{|l|c|c|}
\hline $\begin{array}{l}\text { Average composition of mine } \\
\text { gases from the working and } \\
\text { liquidated mines }\end{array}$ & $\begin{array}{c}\text { liquidated } \\
\text { mines }\end{array}$ & $\begin{array}{c}\text { working } \\
\text { mines }\end{array}$ \\
\hline $\mathrm{CH}_{4}$ & $40-80 \%{ }_{\text {obj. }}$ & $45 \%{ }_{\text {obj. }}$ \\
$\mathrm{CnH}_{\mathrm{m}}$ & $<50 \mathrm{ppm}$ & $0.5 \%{ }_{\text {obj. }}$ \\
$\mathrm{CO}_{2}$ & $8-15 \%{ }_{\text {obj. }}$ & $2.5 \%{ }_{\text {obj. }}$ \\
$\mathrm{O}_{2}$ & lack & $10 \%{ }_{\text {obj. }}$ \\
$\mathrm{N}_{2}$ & the rest & the rest \\
\hline
\end{tabular}

The successful possibility of the utilization of methanepoor mixtures, such as ventilation air from coal mines depends on engineering solution, catalyst used and methane concentration in the mixture with air ${ }^{\mathbf{1}, \mathbf{6}}$.

The process of methane oxidation in the presence of the catalyst proceeds at temperatures lower than the flame oxidation but it is necessary to heat the catalyst and gases up to the temperatures corresponding to the working temperatures of the catalysts. The temperature range at which the oxidation of methane can be proceeded is a characteristic feature of the catalytic system and covers the beginning of the reaction and the total oxidation of methane into carbon dioxide (Fig. 1). The complete flameless combustion of methane takes place when the catalytic system and the utilized gases reach the temperature required for the complete $(100 \%)$ oxidation of methane.

Methane oxidation is an exothermic reaction and reaction gases and catalyst are warmed by the reaction heat. If the energetic effect of the utilization zone resulting from the balance of heating the system by methane oxidation reaction heat and cooling by the colder fresh gases is able to sustain the working temperature, the process of methane oxidation will proceed without any outer source of energy. If the utilization zone does not ensure the heating of the catalyst and fresh cold gases up to the catalyst's working temperature, it is necessary to supply energy into the system for the oxidation of methane. Heating a huge amount of ventilation air up to the working temperatures of the catalyst seems to be an expensive solution, having only ecological values. But if the energetic effect of cata-

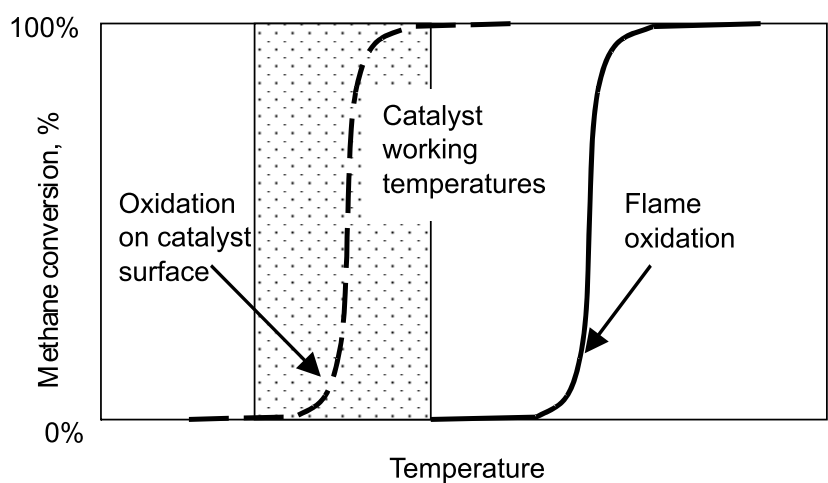

Figure 1. The temperatures of the catalytic and flame oxidation of methane

lytic oxidation of methane ensures a considerable heating of the utilized gases, these hot reaction gases may be used for the production of thermal and electric energy. The catalytic system may consist of a few layers, each of them should be active at different temperatures. The oxidation process can be initiated over very active, a low-temperature catalyst and then it may be continued on the lessactive, high-temperature catalysts working at different temperatures. The application of such method is possible for the combustion of the VAM when the ventilation gases are enriched in drained methane.

Employing the catalysts for the removal of methane from coal mine ventilation air requires not only ensuring the proper working temperatures but a removal from that air the compounds poisoning the catalyst is also required.

The studies that have been carried out for many years, made it possible to find the active oxide and metallic catalytic systems for the reaction of methane oxidation?. For the utilization of gases with low-concentrated methane it seems to be economically well-justified to use the low-temperature catalysts. The comparison of the temperatures of the starting point and the point of the total oxidation of methane for oxide and metallic catalytic systems is presented in Fig. 2.

The supported palladium catalysts of the $\mathrm{Pd}-\mathrm{PdO} / \mathrm{sup}$ port type are the most suitable for the beginning of oxidation ${ }^{10}$. Such catalysts are characterized by a high activity at low palladium content, even below $1 \mathrm{wt} . \%$. Their activity increases with the increased dispersion of the active phase, with its interactions with the support and with, resulting from the mentioned properties, the ability to exchange oxygen with the gaseous phase ${ }^{\mathbf{1 1}, \mathbf{1 2}}$.

Both metallic palladium and its oxide are active in the methane oxidation process. Palladium catalysts enable starting the oxidation of methane at temperatures below $573 \mathrm{~K}$ and reaching the total oxidation of methane at 823 $\mathrm{K}$, when the crystallite size on the catalysts' surface is lower than $6.6 \mathrm{~nm}$. Water vapour and carbon dioxide have a retarding effect on the catalyst activity. The growing concentrations of water vapour and carbon dioxide result in the decrease of the catalyst activity ${ }^{\mathbf{1 3}}$. The highly dispersed palladium catalysts are more sensitive to the presence of carbon dioxide than those with a smaller dispersion of palladium. In spite of this, even the high-dispersed palladium catalysts enable the oxidizing of methane at the temperatures below $623 \mathrm{~K}$ and achieving the total oxidation at $923 \mathrm{~K}$, even in the case of the high concentrations $(\sim 60 \%)$ of carbon dioxide (Fig. 3A) or water vapour (20\%) (see Fig. 3B). 


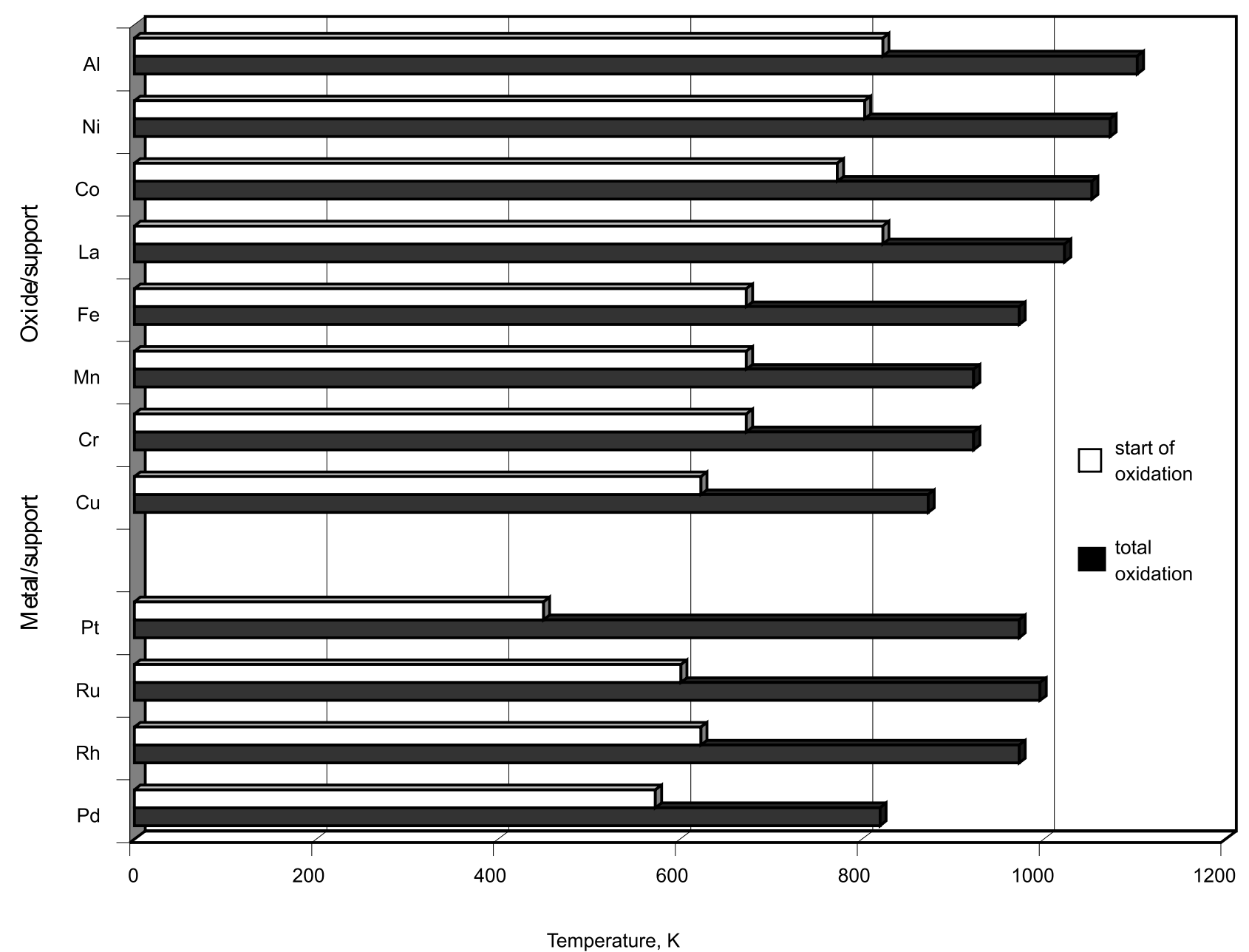

Figure 2. The comparison of the temperatures of the starting point and the total oxidation of methane for oxide and metal catalytic systems in the mixture of $2 \% \mathrm{CH}_{4}+20 \% \mathrm{O}_{2}+78 \% \mathrm{~N}_{2}$

A)

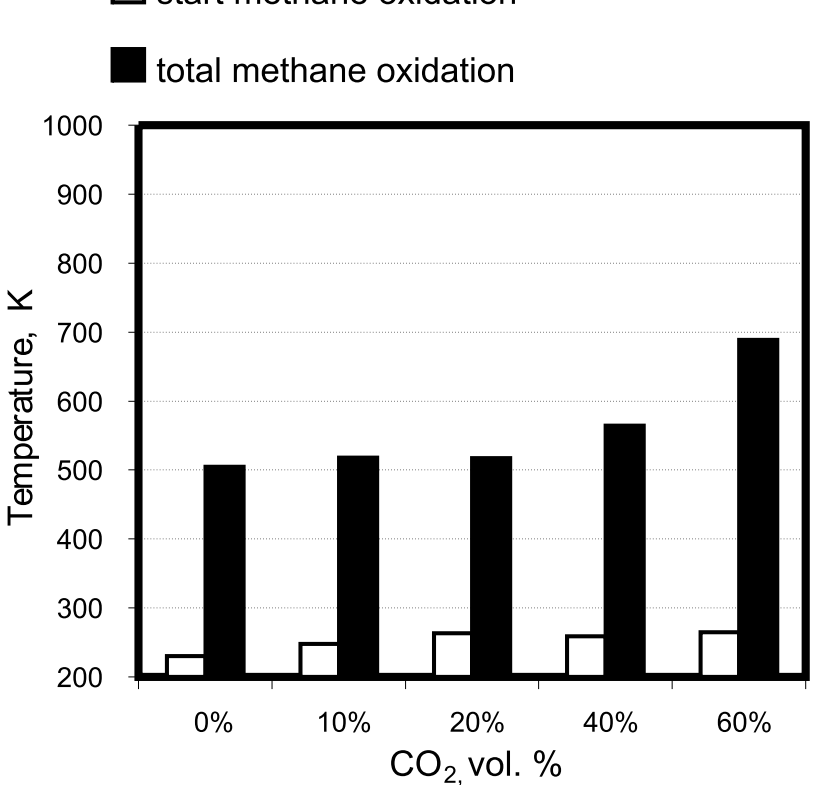

B)

start methane oxidation

total methane oxidation

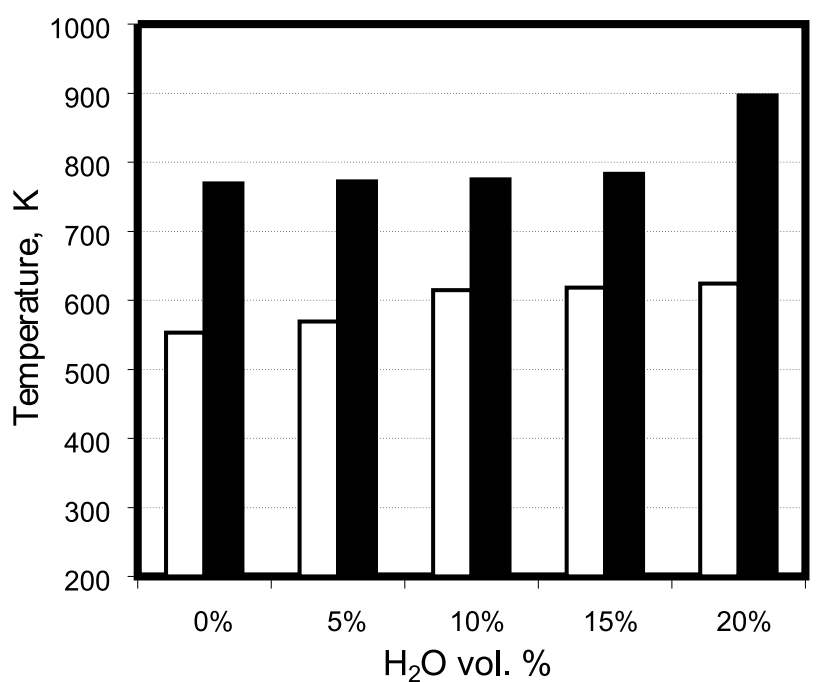

Figure 3. The effect of $\mathrm{CO}_{2}$ (a) and steam (b) addition on methane oxidation over Pd.(4.6nm/ $\left./ \mathrm{Al}_{2} \mathrm{O}_{3}\right)$ catalyst

The palladium catalysts are sensitive also to the presence of such gases as volatile sulfur compounds in the reaction mixture. Because sulfur is poisonous for those catalysts, it is advisable to dry and remove sulfur compounds from the ventilation air, even by the application of the simple adsorption methods.

Although catalysts for methane utilization are well known, the low concentration of methane and the costs of its utilization cause that only few technologies of the catalytic oxidation of methane in coal mine ventilation air were developed on the world market. The technologies and installations for the small field trials, full-scale trials and the commercial scale of the methane utilization from ventilation air are: the thermal flow-reversal reactor (TFRR -- Vocsidizer), the catalytic flow-reversal reactor (CFRR), the adsorption methane concentrator, the gas 
Table 2. The technology proposed by The United States Environmental Protection Agency for the utilization of methane ${ }^{9}$

\begin{tabular}{|c|c|c|c|}
\hline $\begin{array}{l}\text { Vendor I } \\
\text { System }\end{array}$ & Description & Country & Development Status \\
\hline MEGTEC / VOCSIDIZER® & $\begin{array}{l}\text { Thermal flowreversal Reaktor } \\
\text { (oxidizer) }\end{array}$ & $\begin{array}{l}\text { US and } \\
\text { Sweden }\end{array}$ & Completed small field trial; produced steam \\
\hline $\begin{array}{l}\text { CANMET - Lefebvre Freres Ltd. } \\
\text { CH4MIN }\end{array}$ & \begin{tabular}{|l|}
$\begin{array}{l}\text { Catalytic flowreversal Reaktor } \\
\text { (oxidizer) }\end{array}$ \\
\end{tabular} & Canada & Completed laboratory trials; no heat recovery \\
\hline $\begin{array}{l}\text { EDL / } \\
\text { Carbureted gas turbine (CGT); } \\
\text { Isentropic Systems Ltd }\end{array}$ & $\begin{array}{l}\text { Lean-fueled }(1.6 \%) \text { Solar gas } \\
\text { turbine with patented combustor }\end{array}$ & Australia & $\begin{array}{l}\text { Undergoing full-scale trials with simulated } \\
\text { VAM; results delayed }\end{array}$ \\
\hline $\begin{array}{l}\text { CSIRO / } \\
\text { Lean-fueled turbine with catalytic } \\
\text { combustor }\end{array}$ & $\begin{array}{l}\text { Lean-fueled }(1.0 \%) \text { gas turbine } \\
\text { with catalytic combustor }\end{array}$ & Australia & $\begin{array}{l}\text { Research phase scheduled to be complete in } \\
1 \text { to } 2 \text { years }\end{array}$ \\
\hline $\begin{array}{l}\text { FlexEnergy / } \\
\text { Lean-fueled catalytic microturbine }\end{array}$ & $\begin{array}{l}\text { Lean-fueled Capstone } \\
\text { microturbine }(1.3 \%)\end{array}$ & US & Field-tested a $30 \mathrm{~kW}$ unit on simulated VAM \\
\hline $\begin{array}{l}\text { Ingersoll-Rand / } \\
\text { Lean-fueled recuperated } \\
\text { microturbine }\end{array}$ & $\begin{array}{l}\text { Lean-fueled }(1.0 \%) \text { IR Power } \\
\text { Works microturbine }\end{array}$ & US & $\begin{array}{l}\text { Factory-tested a } 70 \mathrm{~kW} \text { unit on } \\
\text { simulated VAM }\end{array}$ \\
\hline $\begin{array}{l}\text { CSIRO / } \\
\text { Hybrid coal and VAM fueled gas } \\
\text { turbine }\end{array}$ & $\begin{array}{l}\text { Waste coal and VAM cofired in } \\
\text { rotary kiln; compressed air } \\
\text { heated in heat exchanger } \\
\text { powers a gas turbine } \\
\end{array}$ & Australia & $\begin{array}{l}\text { Factory-tested a } 1.2 \mathrm{MW} \text { unit on waste coal } \\
\text { and simulated VAM }\end{array}$ \\
\hline $\begin{array}{l}\text { Environmental C\&C / VOC } \\
\text { concentrator }\end{array}$ & Fluid bed adsorbent concentrator & US & $\begin{array}{l}\text { Bench-scale tests did not produce satisfactory } \\
\text { results }\end{array}$ \\
\hline EDL / Ancillary VAM use & $\begin{array}{l}\text { VAM used as combustion air in } \\
\text { Caterpillar } 1 \mathrm{MW} \text { engines }\end{array}$ & Australia & $\begin{array}{l}\text { Successfully operated at commercial } \\
\text { scale }\end{array}$ \\
\hline
\end{tabular}

turbine (CGT), the catalytic combustion gas turbines (CCGT) and the micro turbines with the catalytic combustion units $\mathbf{1 , 4 , 9}$. There are already a few installations operating in the world. They enable the energetic use of the VAM, even if the methane concentration is only $0.1 \%$. Table 2 presents a comparison of some engineering solutions supported on the catalytic or flame oxidation of methane from coal mine ventilation air.

The most interesting but a slightly more complicated solution could be the reverse catalytic reactor produced by the Canadian CANMET. It may be used even if the methane concentration is equal to $0.1 \%$. That apparatus does not need any additional methane to be added to the utilized ventilation air.

In Poland methane management from the ventilation air is an important ecological problem. Introduction of carbon dioxide emission trade and the adequately motivated fees for carbon dioxide and methane emissions can be a factor activating the development of utilization technologies of methane from mine ventilation air and using it in practice for energy production.

\section{LITERATURE CITED}

(1) United States Environmental Protection Agency Assessment of the Worldwide Market Potential for Oxidizing Coal Mine Ventilation Air Methane, EPA 430-R-03-002, July 2003, http://www.epa.gov/coalbed/pdf/ventilation_air methane.pdf.

(2) Karaczun Z. M., Kassenberg A., Sobolewski M.: Polityka ochrony klimatu w Europie Środkowej i Wschodniej raport krajowy - Polska, http://www.ine-isd.org.pl/rozne/REC_raport _klimatyczny.pdf.

(3) Informator No 8, Państwowy Instytut Geologiczny, 2004.

(4) Nawrat S.: Możliwości wykorzystania metanu z powietrza wentylacyjnego podziemnych kopalń węgla, Bezpieczeństwo Pracy i Ochrona Środowiska w Górnictwie, 2006, No 5, 16 $-20$.

(5) Nawrat S., Szlązak N., Jakubow A.: Klimatyzacja centralna w KWK „Pniówek” Jastrzębskiej Spółki Węglowej
S.A. - pierwsza w Polsce, Proccedings of the 7th International Mine Ventilation Congress, June $17-22$.

(6) Su Shi, Beath A., Guo H., Mallett C.: An assessment of mine methane migration and utilisation technologies, Progress in Energy and Combustion Science 2005, 31, 123 170.

(7) Macuda J., Zawisza L.: Występowanie metanu w złożu węgla brunatnego KWB „Bełchatów S.A.”, Wiertnictwo Nafta Gaz, 2005, 22/1, 233 - 238.

(8) Skorek J., Kalina J., Backhaus C., Mroz A.: Możliwości wykorzystania metanu z pokładów węgla w niemieckich i polskich kopalniach, http://www.itc.polsl.pl/kalina/publikacje/ 25.pdf.

(9) Carothers F. P., Schultz H. L., Talkington C. C.: Mitigation of Methane Emmissions from Coal Mine Ventilation Air: An Update, http://www.irgltd.com/Resources/Publications/US/2003-05\%20Mitigation \%20of\%20 Methane $\begin{array}{lllllllllllllllllll}\% & 2 & 0 & \mathrm{E} & \mathrm{m} & \mathrm{i} & \mathrm{s} & \mathrm{s} & \mathrm{i} & \mathrm{o} & \mathrm{n} & \mathrm{s} & \% & 2 & 0 & \mathrm{f} & \mathrm{r} & \mathrm{o} & \mathrm{m}\end{array}$ $\% 20$ Coal\%20Mine \%20Ventilation\%20Air\%20Update.pdf

(10) Machocki A., Denis A., Stasińska B., Gac W.: Metal and oxide catalysts for methane combustion, Polish Journal of Environmental Studies, 2001, 10, Supl.II, 72 - 76.

(11) Machocki A., Stasińska B., Gac W.: Alumina supported palladium catalysts with varied metal dispersion for complete oxidation of methane, Catalytic Combustion, P. Forzatti, G. Groppi, P. Ciambelli, D. Sannino (Eds.), Polipress, Milano, 2005, vol. 2, 155 - 160.

(12) Machocki A., Stasińska B., Gac W.: Why does the activity of $\mathrm{Pd} / \mathrm{Al}_{2} \mathrm{O}_{3}$ catalysts depend on the dispersion of palladium phase?, Polish Journal of Chemical Technology, 8 (2006) 93 - 96 .

(13) Stasińska B., Machocki A.: Influence of carbon dioxide on catalytic combustion of methane derived from domestic waste disposals and underground coal mine ventilation air, The 1th International Seminar on Application of Catalysis in Environmental Protection (11th International Seminar on Catalytic DeNO ${ }_{x}$ ), Lublin, 31.08. - 2.09.2006, 62 - 66. 